\title{
Assessment of DRAINMOD-NII Model for Prediction of Nitrogen Losses Through Subsurface Drained Sandy Clay Under Cultivation in South West Punjab, India
}

MEHRAJ U DIN DAR ( $\sim$ mehrajudindar24@gmail.com )

Punjab Agricultural University

J.P. Singh

Punjab Agricultural University

\section{Research Article}

Keywords: Subsurface Drainage, Rice-wheat system, Drainage rate, Nitrogen losses, DRAINMOD-NII

Posted Date: October 28th, 2021

DOI: https://doi.org/10.21203/rs.3.rs-652918/v1

License: (c) (1) This work is licensed under a Creative Commons Attribution 4.0 International License.

Read Full License 
3 Mehraj U Din Dar*, J.P. Singh

4 Department of Soil and Water Engineering, Punjab Agricultural University, Ludhiana,141004, Punjab, $5 \quad$ India

$6 \quad *$ Corresponding author: Mehraj U Din Dar

$7 \quad$ Email address:mehrajudindar24@gmail.com

\section{ABSTRACT}

In the present study, DRAINMOD-NII model was calibrated for the years 2018-2019 and validated

11 for the period 2019-2020 over the two cropping years. The model simulations were statistically evaluated

12 by comparing the measured drain flows and nitrate-nitrogen $\left(\mathrm{NO}_{3}-\mathrm{N}\right)$ with the model simulated drain

13 outflows and nitrate loss. The study results depicted closer agreement between the simulated and observed

14 results for both the calibration and validation periods. The Root Mean Square Error (RMSE) of the drainage

15 rate was $8.88 \mathrm{~cm}$ more than observed data, $15.41,0.53$ and $0.57 \mathrm{~cm}$ were the values recorded for PBIAS,

16 modelling efficiency (NSE) and $\mathrm{R}^{2}$. The similar parameter values for nitrogen load were recorded to be

$170.14,2.76,0.84$ and 0.88 respectively during the calibration period for rice wheat system. The model was

18 statistically tested during the validation period also, confirming DRAINMOD-NII has the capability to

19 simulate nitrogen losses from the area subjected to subsurface drainage system

20 Keywords: Subsurface Drainage, Rice-wheat system, Drainage rate, Nitrogen losses, DRAINMOD-NII

21

22 


\section{Introduction}

A major source of surface and groundwater pollution has been attributed to drained agricultural lands (Stoate et al., 2001; Randall and Mulla, 2001). Extensive use of manure and fertilizers to boost the

production of food production can increase the risk of nitrogen $(\mathrm{N})$ contamination of surface water and groundwater, promoting eutrophication (Carpenter et al., 1998). Nitrate-nitrogen $\left(\mathrm{NO}_{3}-\mathrm{N}\right)$ polluted drainage waters have been described as a key non-point source of surface water contamination (Jacobs and Gilliam, 1985; David et al., 1997).In highly productive agricultural areas with poorly drained soils, seasonal perched water tables, or shallow groundwater, subsurface drainage is the most widely used water management technique. This method of water management boosts crop production, lowers risk, and enhances crop producers' income.

In Punjab, the problem of waterlogging is widespread across all the Muktsar blocks, which is one of the districts of Punjab. In the last three decades, the water table has risen steadily, and coming closer to 1 meter or less from the surface over large areas (Government of Punjab, 2008). The percentage of waterlogged areas increased from $62.54 \%$ of Punjab's total waterlogging area in 1998 to $89.17 \%$ in

41 Muktsar district in 2006. (Singh, 2012). The issue is widespread throughout all blocks of the Muktsar

42 district (Muktsar, Lambi, Gidderbaha and Malout). In several villages, the water level rises nearly to the 43 surface during the rainy season, causing significant harm to standing crops. Water logging and soil salinity 44 are thus an inevitable off-flow of irrigation and have a detrimental effect on the output and productivity of 45 irrigation control areas in the south-west of Punjab, resulting in enormous economic losses. Therefore, 46 serious questions about the long-term viability of irrigated agriculture have been rightly raised, unless the 47 problem of environmental degradation is not properly addressed. Initiation of the water logging problem, 48 its scope and degrees, in this part of Punjab are regulated by several variables. The vast network of unlined 49 canal distribution and their field channels recharge the ground water body due to infiltration from and return 50 of irrigation into the fields accounts for one of the reasons of water logging in Punjab. The two major lined 51 canals, i.e., the Rajasthan feeder and Sirhind feeder running parallel to the east of the district of Muktsar, 
52 although lined cause major damage to the region due to cracks in the lining of their bed and sides, by the

53 inflow of excess water into the area. Water logging is also responsible for the inadequate operation of the

54 current surface drainage system. With the development of canal network, the parallel drains have not been

55 properly built. The maintenance of these drains is of very low standard, except where drains have been

56 properly installed. Owing to low groundwater quality, there is much less withdrawal of underground water

57 for irrigation. The water table rise in this area is also caused by the lateral movement of groundwater flow

58 from South-West to North-Eastern areas, the water table depth contours from North-West Punjab to

59 Bathinda and Malout towns with an average travel rate of about $0.29 \mathrm{kms}$ per year (Uppal and Mangat,

60 1981). The cropping pattern of the district of Muktsar, commonly known as the cotton belt in the South-

61 West area of Punjab, has also changed. For several reasons, the share of other crops decreased from 40.13

$62 \%$ in $1995-96$ to $10.51 \%$ in $2009-10$. (Gupta, 2002). Wheat, the main food grain, has always remained very

63 environment friendly. In the district, it has been the major rabi crop. Roughly $44.50 \%$ of the total cropped

64 area in that district was under wheat in 1995-96, which increased marginally to $45.65 \%$ in 2009- 10. (Ladha

65 et al., 2000). Paddy, which was originally grown in the district's waterlogged field, is now the second main

66 crop. It was barely grown in $1995-96$ on $1.57 \%$ of the area and is now the second dominant crop with

$6722.27 \%$ of the total cropped area recorded in 2009-10. Cotton has always remained the traditional crop of

68 the Muktsar district. The area under cotton that occupied $15.21 \%$ of the gross cropped area increased in

$69 \quad 1995-96$ to $21.38 \%$ in 2009-10 (Gupta, 2006). However, due to changing climate conditions, and rising

70 water table, the annual variations in the yield and area under various major crops declined. The water table

71 is increasing at an alarming pace in this region of Punjab. In the irrigation control area of this region in

72 Punjab, water logging adversely affects the cropping pattern and crop productivity, resulting in enormous

73 socio-economic losses. Cotton is completely substituted by paddy due to the problem of water logging.

74 Earlier cotton covered $80 \%$ of the region's total area, but now it is completely eliminated from the

75 cultivation process, due to its sensitiveness to excess water stress. Due to relative drawbacks, sugarcane,

76 serson and other crops were also eliminated from cultivation. The yields of the most important crops such

77 as wheat and paddy have decreased to almost 50 percent compared to normal soil (Gupta, 2006). This has 
raised production costs because more fertilizers, pesticides and insecticides are being used by farmers to

79 improve crop productivity. $\mathrm{NO}_{3}-\mathrm{N}$ is the common contaminant to the groundwater reservoir, due to excess

80 use of fertilizers, in the region. Waterlogging has led to a significant decrease in net returns from crop

81 production and income from farmers, thereby affecting the well-being of the rural population in this Punjab

82 region. A burning problem in the Punjab economy is debt and suicides, especially among marginal and

83 small farmers, due to low net returns from agriculture. Since 2016, government of Punjab, has initiated

84 many schemes for the reclamation of these areas, mostly affected by waterlogging and excess salinity.

85 Subsurface drainage technology, is one among the initiatives, which has been undertaken to reclaim 12,882

86 acres of waterlogging affected areas in this district of Punjab. DRAINMOD-NII which is a field scale

87 model, was developed for poorly and artificially drained lands to simulate their hydrology. The calibration area should be of field scale size, with installed subsurface drainage system (SSD), that should reflect field conditions. The calibration area for agricultural fields should usually consist of not less than three lateral drains, developed to continuously measure drain flow rates and water table behaviour in between the laterals

91 (Skaggs et al., 2012). Furthermore, the modeled region should represent normal drainage boundary

92 conditions. The main objective of this study was to evaluate the DRAINMOD-NII model for Punjab 93 conditions, determining the volume of drainage and nitrogen losses from a newly installed subsurface 94 drainage system at Thehri, Muktsar, Punjab, in order to validate its design for better crop conditions and, 95 as a result, minimize nitrogen loss to surface and subsurface waters from these reclaimed areas.

\section{2. Methodology}

\section{$97 \quad 2.1$ Site description}

The experimental site was established at Thehri, Muktsar, Punjab, some $35 \mathrm{~km}$ from the district headquarters of Bathinda, for DRAINMOD-N II model evaluation (Fig.1). The total cultivated area selected was 4.5 hectares. The study site's soil texture ranges from sandy clay to clay loam and extends up to 2 meters below ground level (bgs). With an EC of more than $7 \mathrm{dS} / \mathrm{m}$ and a hydraulic conductivity of 0.43 $\mathrm{m} /$ day $(1.8 \mathrm{~cm} / \mathrm{hr})$, the soil is saline. The groundwater is shallow, with a depth of $60-70 \mathrm{~cm} \mathrm{bgs}$ on an 103 average. The source of irrigation is canal water, from Indira Gandhi canal located at $2 \mathrm{~km}$ from the study 
area. The average $\mathrm{NO}_{3}-\mathrm{N}$ concentration in irrigation water was recorded to be 3-4 mg/l. The subsurface drainage system was installed in the study area under the Agricultural Credit Association (ACA) (Mihir Shah Project) Project Division 1, Drainage Gidderbaha, Subsurface Drainage System, Village Thehri, Pocket No.2. The layout of the experimental field is shown in Fig. 2. The laterals were installed at $1.9 \mathrm{~m}$ bgs depth and $30 \mathrm{~m}$ bgs spacing throughout the field, having multiple laterals and single collector which is joined to a sump, where the drain water is continuously being pumped out by a $2.2 / 3.0(\mathrm{Kw} / \mathrm{HP})$ pump motor assembly (Fig.3). The water table depth was observed through observation wells installed all over

111 the field (Fig.4). The field was cultivated with rice during the summer season of 2018 followed by wheat 112 crop during the winter season of 2018/2019.The same cropping pattern was followed for the year 2019 and 1132020 respectively. The agricultural management practices were kept similar during all the growing seasons. 114 The rice seasons were under flood irrigation, whereas the wheat crop was irrigated based on grower's 115 recommendation. The drainage water quality was analysed for nitrate concentration at the outlet, twice in 116 a month, during the whole season. Rice was cultivated in June 2018 and harvested in October 2018, 117 followed by wheat in November and harvesting in April 2019.The similar dates were repeated for the years 1182019 and 2020 respectively. "Field preparations were carried out by adding farmyard manure to improve 119 the soil chemical properties. Urea with $46.6 \%$ Nitrogen was applied at a rate of $287 \mathrm{~kg} / \mathrm{ha}$ for rice and 337 $120 \mathrm{~kg} / \mathrm{ha}$ for wheat during the two growing seasons. During the two seasons other fertilizers like granule sulfur, 121 soft sulfur, super phosphate, Nitrate- nitrogen (33.3\%) were also added to increase the crop productivity. 122 The crop residues after rice harvest were incorporated in the soil, before the beginning of the next wheat 123 crop. 


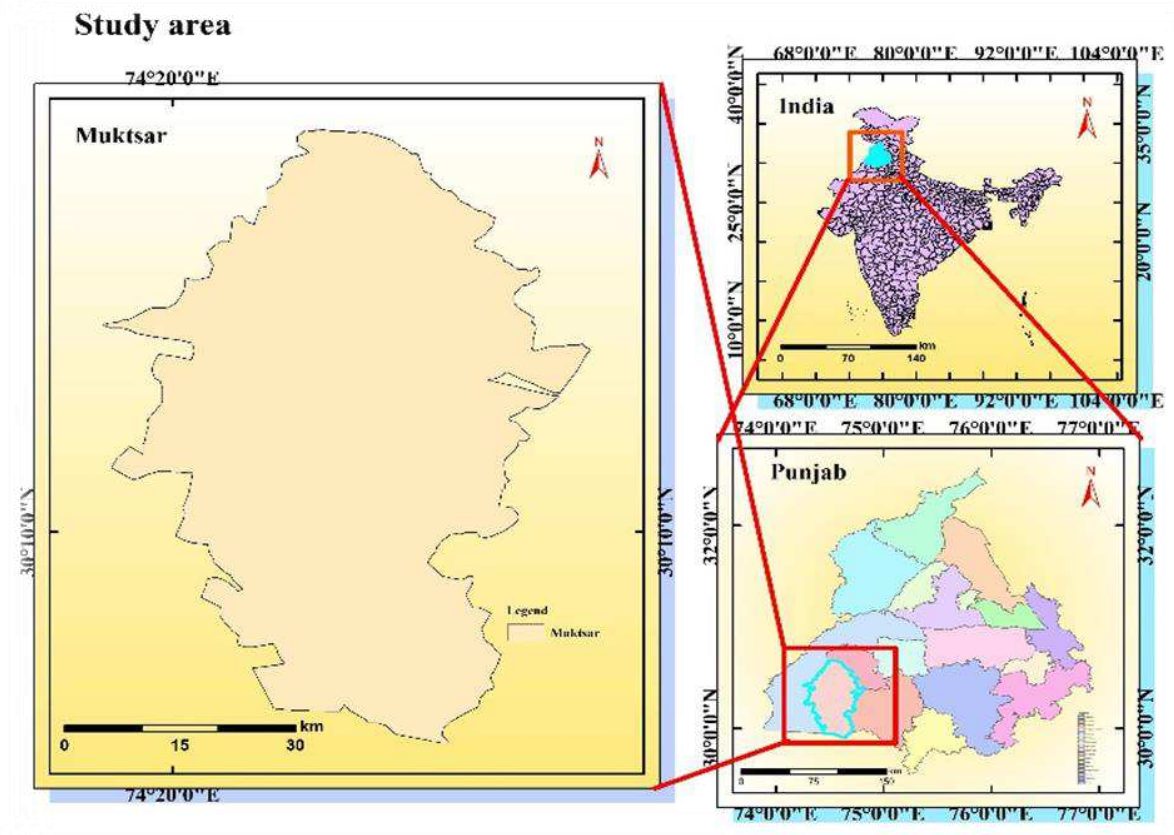

Fig.1.Study area location

PROJECT DIVISION NO. 1 DRAINAGE GIDDERBAHA

LAYOUT PLAN OF SUBSURFACE DRAINAGE SYSTEM AT VILLAGE THERI POCKET NO 2

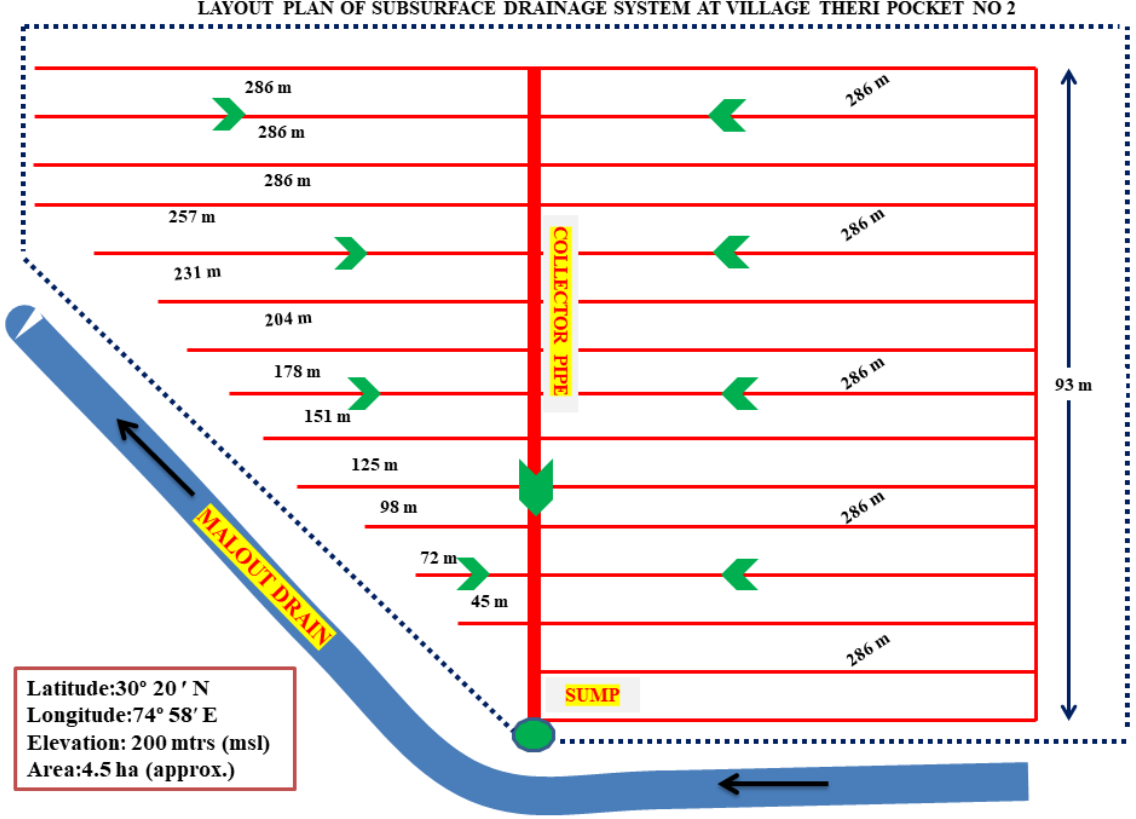

127 Fig.2.Installed subsurface drainage system layout at Thehri, Muktsar 

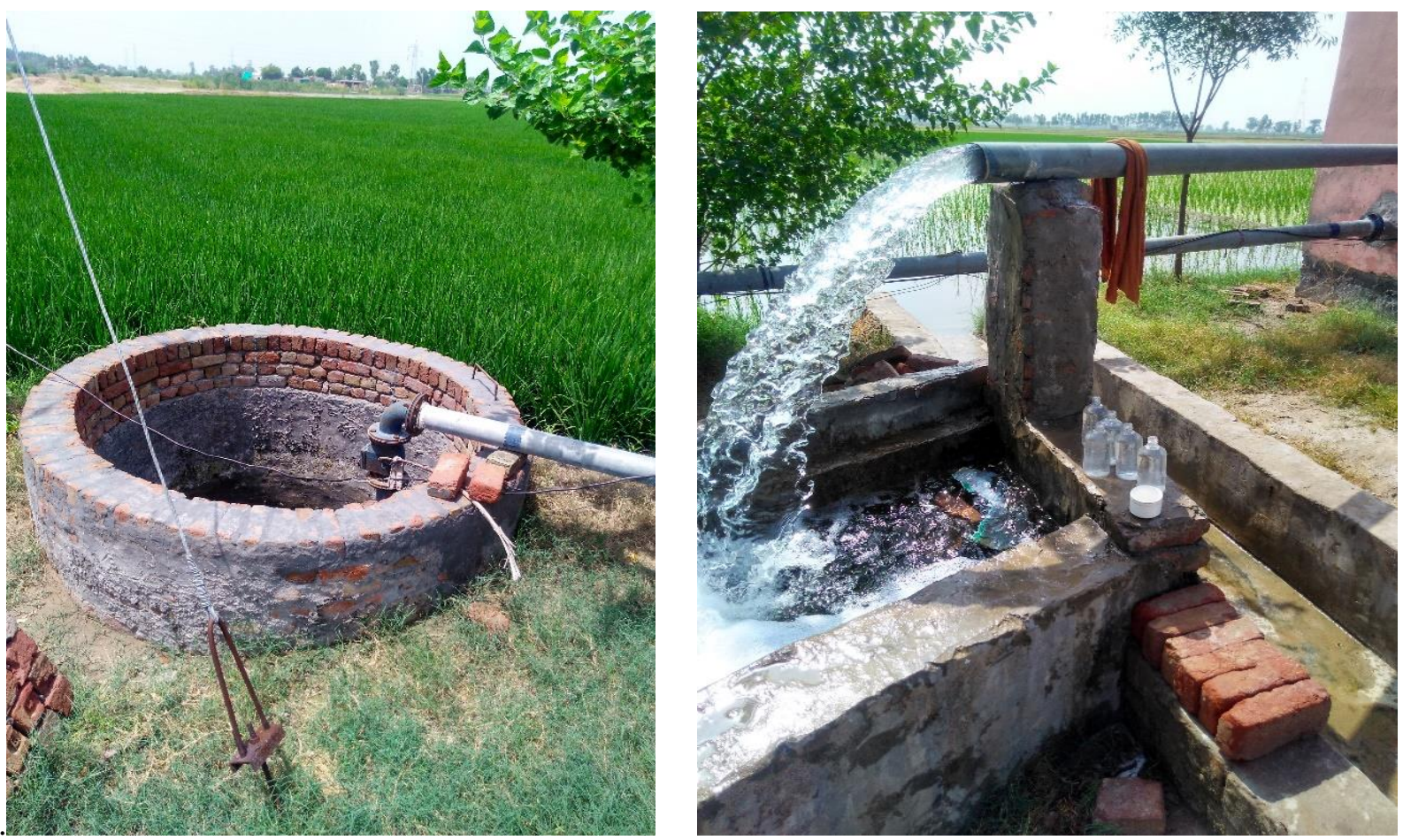

Fig.3. Sump well and water being drained out
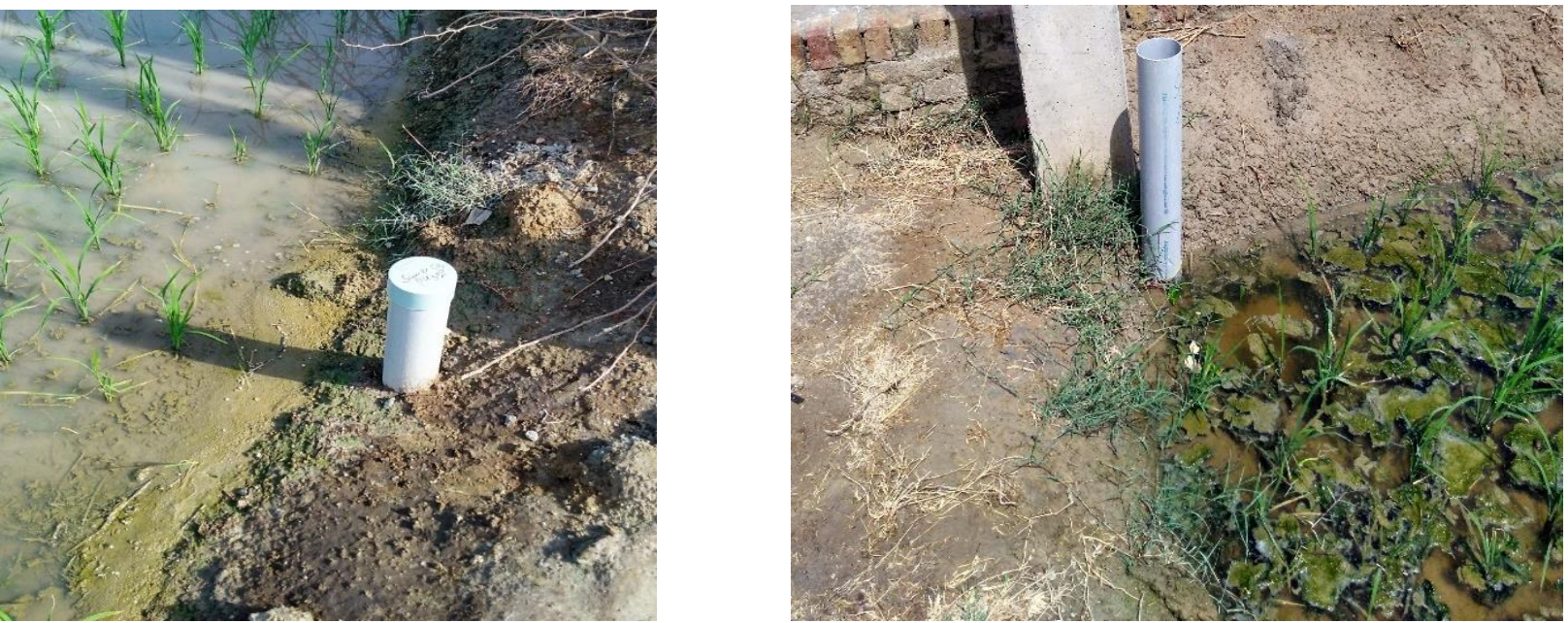

\section{Fig.4. Observation wells for measuring water table depth}

\subsection{Simulation procedure}

Model simulations were performed, using the data from the study area (Fig.1). Input parameters

134 included soil properties, meteorological parameters, crop characteristics, drainage system design

135 parameters and irrigation (Table 1). Parameters related to Nitrogen, including $\mathrm{N}$ transport and 136 transformation, organic matter parameters and crop management were required for DRAINMOD-NII 
simulation. Precipitation data was obtained from Bathinda weather station, Punjab Agricultural University. Irrigation was applied to the crops on weekly basis for rice and after a fortnight for wheat crop. Potential evapotranspiration (PET) depends on net radiation, wind velocity and humidity within the region. Daily PET was computed, using Thornthwaite method (1948), in the model using weather data from 20182020.Soil samples were collected for various soil parameters and nitrate content form different locations using gps based, sampling points, considering the latitude and longitude of that particular point. The samples were collected from various depths to a maximum depth of $1.8 \mathrm{~m}$, between the laterals. Hydraulic conductivity was measured insitu, during both the rice and wheat seasons, using augur hole method and an average representative value was selected for the whole study area. Soil properties at the study area are listed in Table 2. DRAINMOD-NII simulates cropping systems, comprising more than one crop. The simulation study was based on rice wheat cropping rotation, which takes almost one year to complete. The study was repeated for the two years having rice wheat cropping system. The input data for each crop consist of the major dates of planting, the effective rooting depth, harvesting and stress counting parameters. “Crop parameters included $\mathrm{N}$ uptake and yield parameters. Yield parameters of harvest index (HI), root/shoot ratio (RSR), $\mathrm{N}$ content of plant grains, roots, shoots and potential crop yield were included in the model. The $\mathrm{N}$ uptake during the entire growing season is estimated from yields parameters by DRAINMOD-N II model. The maximum crop yield obtained in absence of soil water related stresses is defined as the potential crop yield by Evans et al. (1991). In DRAINMOD the crop yield was calculated based on the product of potential yield and the DRAINMOD predicted relative yield. The ratio of crop yield to the total above-ground biomass is defined as the Plant HI by Hay (1995). Hoad et al. (2001) described 157 the RSR as the mass ratio between root dry matter and shoot dry matter. The HI and RSR are used by the DRAINMOD-N II model to estimate nongrain above-ground dry matter and below-ground dry matter from DRAINMOD-N II predicted or field-measured crop yields (Youssef et al., 2005). Table 3 shows the possible yields and nitrogen content of rice wheat based on field measurements. Salazar et al. (2009) listed the popular ranges of rice wheat crop N, C, and lignin contents as in Table 3. The N-uptake tabulated feature proposed by Youssef et al. (2003) and Shedekar et al. (2021) was used for crop modeling in addition to the 
164 field data.

165 Table 1 Parameters for drainage design considered in the model

\begin{tabular}{|l|l|}
\hline Parameters & Value \\
\hline "Drain depth, (cm) & 198.12 \\
\hline Drain spacing, (cm) & 3048 \\
\hline Drainage coefficient, (cm/day) & 2.35 \\
\hline Impermeable layer depth form surface, $(\mathrm{cm})$ & 350 \\
\hline Effective drain radius, (cm) & 1.5 (for 4in dia lateral pipe) \\
\hline Maximum surface storage, Sm (cm) & 1.5 \\
\hline Surface micro-storage, SI $(\mathrm{cm})$ & 0.75 \\
\hline Initial depth to water table $(\mathrm{cm}) "$ & 60 \\
\hline
\end{tabular}

Table 2 Soil properties of study area

\begin{tabular}{|c|c|c|c|c|c|c|c|c|}
\hline $\begin{array}{c}\text { Soil } \\
\text { Layer }\end{array}$ & Thickness(cm) & $\begin{array}{c}\text { Sand } \\
\%\end{array}$ & $\begin{array}{l}\text { Silt } \\
\%\end{array}$ & $\begin{array}{c}\text { Clay } \\
\%\end{array}$ & $\begin{array}{c}\text { Saturated } \\
\text { Water content } \\
\left(\mathrm{cm}^{3} / \mathrm{cm}^{3}\right)\end{array}$ & $\begin{array}{c}\theta_{0.1} \text { bar } \\
\left(\mathrm{cm}^{3} / \mathrm{cm}^{3}\right)\end{array}$ & $\begin{array}{c}\theta_{0.33} \text { bar } \\
\left(\mathrm{cm}^{3} / \mathrm{cm}^{3}\right)\end{array}$ & $\begin{array}{c}\text { Wilting } \\
\text { point } \\
\text { 015 bar } \\
\left(\mathrm{cm}^{3} / \mathrm{cm}^{3}\right)\end{array}$ \\
\hline 1 & $0-15$ & 89.05 & 3.15 & 7.8 & 0.57 & 0.30 & 0.26 & 0.12 \\
\hline 2 & $15-30$ & 83.35 & 8.45 & 8.2 & 0.53 & 0.23 & 0.20 & 0.10 \\
\hline 3 & $30-60$ & 81.15 & 9.85 & 9 & 0.61 & 0.29 & 0.20 & 0.13 \\
\hline 4 & $60-90$ & 79.65 & 10.35 & 10 & 0.61 & 0.28 & 0.22 & 0.12 \\
\hline 5 & $90-120$ & 78.25 & 13.15 & 8.6 & 0.62 & 0.30 & 0.26 & 0.16 \\
\hline 6 & $120-150$ & 80.85 & 9.75 & 9.4 & 0.63 & 0.32 & 0.21 & 0.10 \\
\hline 7 & $150-180$ & 80.25 & 11.35 & 8.4 & 0.68 & 0.36 & 0.29 & 0.12 \\
\hline I & & $K_{\mathrm{cot}}=1$ & $n / h$ & & & & & \\
\hline
\end{tabular}


Table 3 Crop parameters considered in the DRAINMOD-NII model

\begin{tabular}{|c|c|c|}
\hline \multirow[t]{2}{*}{ Input parameters } & \multicolumn{2}{|c|}{ Crop } \\
\hline & Rice & Wheat \\
\hline \multicolumn{3}{|c|}{ Crop data } \\
\hline Planting data & $\begin{array}{l}05-06-2018(05-06-2019 \text { for the } \\
\text { year } 2019\end{array}$ & $\begin{array}{l}08-11-2018(08-11-2019 \text { for the } \\
\text { year 2019) }\end{array}$ \\
\hline Total growing period (days) & 129 & 155 \\
\hline "Input N fertilizer (kg N/ha) & Urea $287.5+$ Ammonium 62.5 & Urea $337.5+$ Ammonium 62.5 \\
\hline $\begin{array}{l}\text { Potential yield (grain/seed) } \\
(\mathrm{kg} / \mathrm{ha})\end{array}$ & 8500 & 6500 \\
\hline Root/Shoot ratio & 0.46 & 0.11 \\
\hline Harvest Index & 0.15 & 0.24 \\
\hline \multicolumn{3}{|c|}{ Plant biochemical composition } \\
\hline Crop Nitrogen $(\%)$ & 2.29 & 1.5 \\
\hline Root N (\%) & 0.91 & 0.5 \\
\hline Root C (\%) & 36.5 & 40 \\
\hline Root lignin (\%) & 9.5 & 8.3 \\
\hline Shoot N (\%) & 1.76 & 0.5 \\
\hline Shoot C (\%) & 41.5 & 40 \\
\hline Shoot lignin (\%)" & 5.7 & 3.5 \\
\hline
\end{tabular}

170 Denitrification, nitrification, fertilizer dissolution, $\mathrm{pH}$ regulation, and volatilization were among the carbon

171 and nitrogen transformation parameters considered in the model simulation. Organic matter parameters

172 define the possible rates of decomposition (Kdec) and $\mathrm{C} / \mathrm{N}$ ratios organic matter and litter in soils (SOM)

173 pools. The model was initialized with $\mathrm{NO}_{3}-\mathrm{N}, \mathrm{NH}_{4}-\mathrm{N}$, and Organic Carbon (OC) concentrations measured 
174 in the region. The model was simulated using the procedure defined by Youssef et al. (2006). The nitrogen

175 initial transport parameters and $\mathrm{NH}_{4}$ distribution coefficient input parameters for DRAINMOD-NII are

176 shown in Table 4. Table 5 shows the values chosen during model calibration. All of the values mentioned

177 were derived from Salazar et al. (2009) and Shedekar et al. (2021).

178 Table 4 Nitrogen transport and transformation parameters for the study area

\begin{tabular}{|c|c|c|}
\hline Parameters & Value & \\
\hline \multicolumn{3}{|l|}{ Nitrogen Transport } \\
\hline "Rain $\mathrm{NO}_{3}-\mathrm{N}$ concentration & 0.32 & \\
\hline Rain $\mathrm{NH}_{4}-\mathrm{N}$ concentration & 0.34 & \\
\hline Air $\mathrm{NH}_{3}-\mathrm{N}$ concentration & 0 & \\
\hline Tortuosity & 0.5 & \\
\hline Longitudinal dispersivity, $\mathrm{cm}$ & 25 & \\
\hline Initial/Boundary Conditions & $15 \mathrm{~cm}$ & $180 \mathrm{~cm}$ \\
\hline Initial $\mathrm{NO}_{3}-\mathrm{N}$ Concentration $(\mathrm{mg} / \mathrm{L})$ & 4.5 & 2.5 \\
\hline Initial $\mathrm{NH}_{4}-\mathrm{N}$ Concentration $(\mathrm{mg} / \mathrm{L})$ & 3.5 & 0.5 \\
\hline \multicolumn{3}{|l|}{ Nitrification parameters } \\
\hline Michaelis-Menton rate constant ( $\mu \mathrm{g}$ N/g soil-day) & 10 & \\
\hline Half-saturation constant ( $\mu \mathrm{g} / \mathrm{Ng}$ soil) & 20 & \\
\hline Optimum temperature $\left({ }^{\circ} \mathrm{C}\right)$ & 25 & \\
\hline Coefficient for Empirical shape & 0.5 & \\
\hline \multicolumn{3}{|l|}{ Denitrification parameters } \\
\hline Michaelis-Menton rate constant ( $\mu \mathrm{g}$ N/g soil-day) & 0.6 & \\
\hline Half-saturation constant (mg/L) & 25 & \\
\hline Optimum temperature $\left({ }^{\circ} \mathrm{C}\right)$ & 30 & \\
\hline Coefficient for Empirical shape & 0.29 & \\
\hline
\end{tabular}




\begin{tabular}{|l|l|}
\hline \multicolumn{2}{|l|}{ Urea Hydrolysis } \\
\hline Michaelis-Menton rate constant $(\mu \mathrm{g} \mathrm{N} / \mathrm{g}$ soil-day $)$ & 50 \\
\hline Half-saturation constant $(\mu \mathrm{g} / \mathrm{L})$ & 50 \\
\hline Optimum temperature $\left({ }^{\circ} \mathrm{C}\right)$ & 51.6 \\
\hline Other processes & $\begin{array}{l} \\
\left(\mathrm{d}^{-1}\right)\end{array}$ \\
\hline Sertilizer dissolution - zero-order rate coefficient & 1 \\
\hline Soil pH at threshold & 0.16 \\
\hline Maximum soil buffering capacity & 7.5 \\
\hline Empirical resistance factor $(\mathrm{s} / \mathrm{cm})$ & 100000 \\
\hline
\end{tabular}

Table 5 Range of parameters of DRAINMOD-NII model during calibration

\begin{tabular}{|l|l|l|}
\hline Parameter & Range & Calibrated Value \\
\hline Hydrology & & \\
\hline "Hydraulic conductivity of 3 & $0.05-100$ & $3.3,0.5,0.5$ \\
layers (Kat), $\mathrm{cm} \mathrm{h}^{-1}$ & & 1.5 \\
\hline $\begin{array}{l}\text { Maximum surface storage, } \mathrm{S}_{\mathrm{m}} \\
\text { (cm) }\end{array}$ & $0.25-10$ & \\
\hline Surface micro-storage, $\mathrm{S}_{\mathrm{I}}(\mathrm{cm})$ & $0.25-10$ & 0.75 \\
\hline Drainage coefficient $\left(\mathrm{cm}^{-1}\right)$ & $0.5-10$ & 2.5 \\
\hline Critical ice content above which & $0.01-0.5$ & 0.2 \\
\hline infiltration stops" & & \\
\hline Nitrate & & \\
\hline
\end{tabular}




\begin{tabular}{|c|c|c|}
\hline "Longitudinal dispersivity, $\mathrm{cm}$ & $5-30$ & 25 \\
\hline \multicolumn{3}{|l|}{ Denitrification parameters } \\
\hline $\begin{array}{l}\text { Michaelis-Menton max rate ( } \mu \mathrm{g} \\
\mathrm{N} \text { g-soil }{ }^{-1} \text { day }^{-1} \text { ) }\end{array}$ & $0.5-60$ & 0.6 \\
\hline $\begin{array}{l}\text { Parameters half-saturation } \\
\text { constant }\left(\mathrm{mg} \mathrm{L}^{-1}\right)\end{array}$ & $1-60$ & 35 \\
\hline Optimum temperature $\left({ }^{\circ} \mathrm{C}\right) "$ & $18.5-74$ & 50 \\
\hline \multicolumn{3}{|c|}{ Transformation parameters for Soil Organic Carbon } \\
\hline $\begin{array}{l}\text { "Active pool decomposition rate } \\
\left(\text { day }^{-1}\right)\end{array}$ & $1 \mathrm{E}^{-2}$ to $4 \mathrm{E}^{-4}$ & $2.00000 \mathrm{E}^{2}{ }^{2}$ \\
\hline $\begin{array}{l}\text { Slow pool decomposition rate } \\
\left(\text { day }^{-1}\right)\end{array}$ & $2.7 \mathrm{E}^{-4}$ to $11 \mathrm{E}^{-4}$ & $5.47945 \mathrm{E}^{-4}$ \\
\hline $\begin{array}{l}\text { Passive pool decomposition rate } \\
\left(\text { day }^{-1}\right)^{\prime \prime}\end{array}$ & $6.2 \mathrm{E}^{-6}$ to $24.7 \mathrm{E}^{-6}$ & $12.3288 \mathrm{E}^{-5}$ \\
\hline
\end{tabular}

181

\subsection{Calibration and verification efficiency}

For simulated and observed drainage outflows and $\mathrm{NO}_{3}-\mathrm{N}$ losses in subsurface drains, the Root

184 Mean Square Error (RMSE), percentage of Bias (PBIAS), coefficient of determination ( $\mathrm{R}^{2}$ ), and modeling 185 efficiency (NSE) were considered and compared using the following statistical formulations:

$186 \quad R M S E=\sqrt{\left(\frac{1}{N} \sum_{i=1}^{N}\left(P_{i}-O_{i}\right)^{2}\right.}$

$187 \quad P B I A S=\frac{100 \sum_{i=1}^{i=n}\left(O_{i}-P_{i}\right)}{\sum_{i=1}^{i=n} O_{i}}$

$188 \quad R^{2}=\frac{\left\{\sum_{i=1}^{N}\left(O_{i}-O\right)\left(P_{i}-P\right)\right\}^{2}}{\sum_{i=1}^{N}\left(O_{i}-O\right)^{2} \sum_{i=1}^{N}\left(P_{i}-P\right)^{2}}$ 
$N S E=1-\left\lfloor\frac{\sum_{i=1}^{i=n}\left(O_{i}-P_{i}\right)^{2}}{\sum_{i=1}^{i-n}\left(O_{i}-\bar{O}\right)^{2}}\right\rfloor$

$O_{i}$ represents the observed value at time $i, P_{i}$ represents the simulated value at time $i$. Obar represents the observed mean value, and $\mathrm{n}$ represents the number of paired observed-simulated values. When the RMSE (Equation (1)) equals 0 (zero), it implies a perfect match between observed and expected values, whereas increasing RMSE values imply a worsening match. According to Singh et al. (2004), RMSE values less than half the standard deviation of the observed (measured) data are considered low and suggest a strong model prediction. Nash-Sutcliffe efficiency (Equation (2)) can range from $-\infty$ to 1, according to Nash and Sutcliffe (1970). An efficiency of $1(E=1)$ corresponds to a perfect match between the simulated and observed results. When the efficiency is zero $(\mathrm{E}=0)$, the model predictions are as accurate as the mean of the observed results. Efficiency less than zero $(\mathrm{E}<0)$ means that the observed mean is a better predictor than the model. The coefficient of determination, $\mathrm{R}^{2}$, (Equation (3)), ranges from 0 to 1 that defines how much of the variance in the calculated data is explained by the model, with higher values meaning less error variance, $\mathrm{R}^{2}>0.5$ is usually considered appropriate (Santhi et al., 2001; Van Liew et al., 2003). The average tendency of the simulated data to be greater or smaller than their observed counterparts is measured by the percentage of bias (PBIAS) (Gupta et al., 1999). PBIAS optimal value is 0, with low magnitude values suggesting a good model simulation. Underestimation bias is indicated by positive values, while overestimation bias is indicated by negative values (Gupta et al., 1999). The results of a statistical analysis were used to verify the model's reliability during the calibration and validation periods, and the results are shown in Table 6 and 7. The significance of $\mathrm{R}^{2}$ was determined using a partial $\mathrm{F}$ test, which revealed a substantial correlation at a 5\% level of significance, as shown in Table 6 and 7 and discussed in sections 3.1.1. and 3.2.1 respectively. 


\section{Results and discussion}

\subsection{Calibration}

\subsubsection{Simulated drainage outflows}

The performance of DRAINMOD in simulating monthly drainage outflows during the calibration period (2018-2019) is summarized in Table 7. The model efficiency (NSE) for monthly flows was 0.53 with a $\mathrm{R}^{2}$ value of 0.57 , PBIAS of 15.41 , and RMSE of 8.88 . These efficiency criteria suggest the model performance to be good (Moriasi et al., 2007) to excellent (Skaggs et al., 2012). The predicted and observed monthly subsurface drainage outflows at Thehri in 2018 and 2019 are compared in Figs.5(a and b), respectively. It is evident from the figures that the model underestimated the drainage outflows except in the months of May, September and October. The under-prediction of subsurface drainage in these months was most likely due to variations in precipitation events at the experimental plots versus the rain gauge site. In both years, the greatest discrepancies between the model simulated and observed monthly drain outflows occurred in March, June, and July. There was less rainfall during this period, but more drainage was observed. The model appears to be more sensitive to rainfall than the observed data suggests. The expected monthly drain outflows were, however, in good agreement with the observed values during all other periods. Overall,48\% of the outflow from the study area was recorded in the months of Jan, March, July, August and December. The comparison between the observed and predicted cumulative drain outflows (Fig.5 a and b) indicated that the simulated annual subsurface drainage depth was only about $74 \mathrm{~cm}$ less than observed drain depth in these two years. "Tian et al. (2012) reported large differences between measured and predicted daily drainage rates. Salazar et al. (2009) also reported higher simulated drainage outflows than measured values during high intensity precipitation events.

Table 6 Model performance during calibration period (2018-2019) for rice wheat cropping system

\begin{tabular}{|l|l|l|l|l|}
\hline Parameter & RMSE & PBIAS & $\begin{array}{l}\text { Nash-Sutcliffe } \\
\text { coefficient (NSE) }\end{array}$ & $\mathbf{R}^{2}$ \\
\hline Drain flow depth & 8.88 & 15.41 & 0.53 & $0.57^{*}$ \\
\hline
\end{tabular}




\begin{tabular}{|l|l|l|l|l|}
\hline Nitrogen load (kg/ha) & 0.14 & 2.76 & 0.84 & $0.88^{*}$ \\
\hline
\end{tabular}

$* \mathrm{R}^{2}$ is statistically significant, using partial $\mathrm{F}$ test for $\mathrm{p}=1$ and $\alpha=5 \%$

237

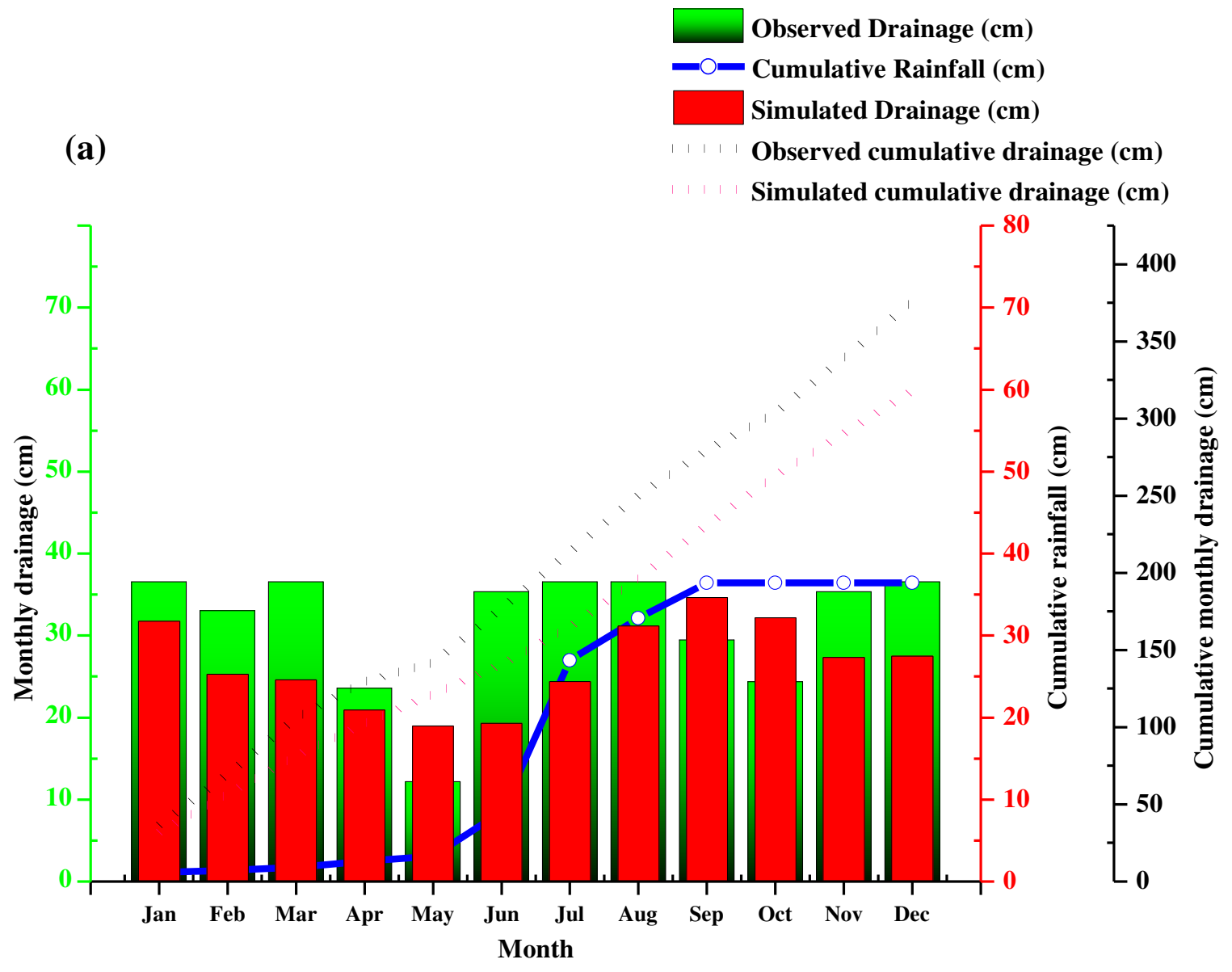




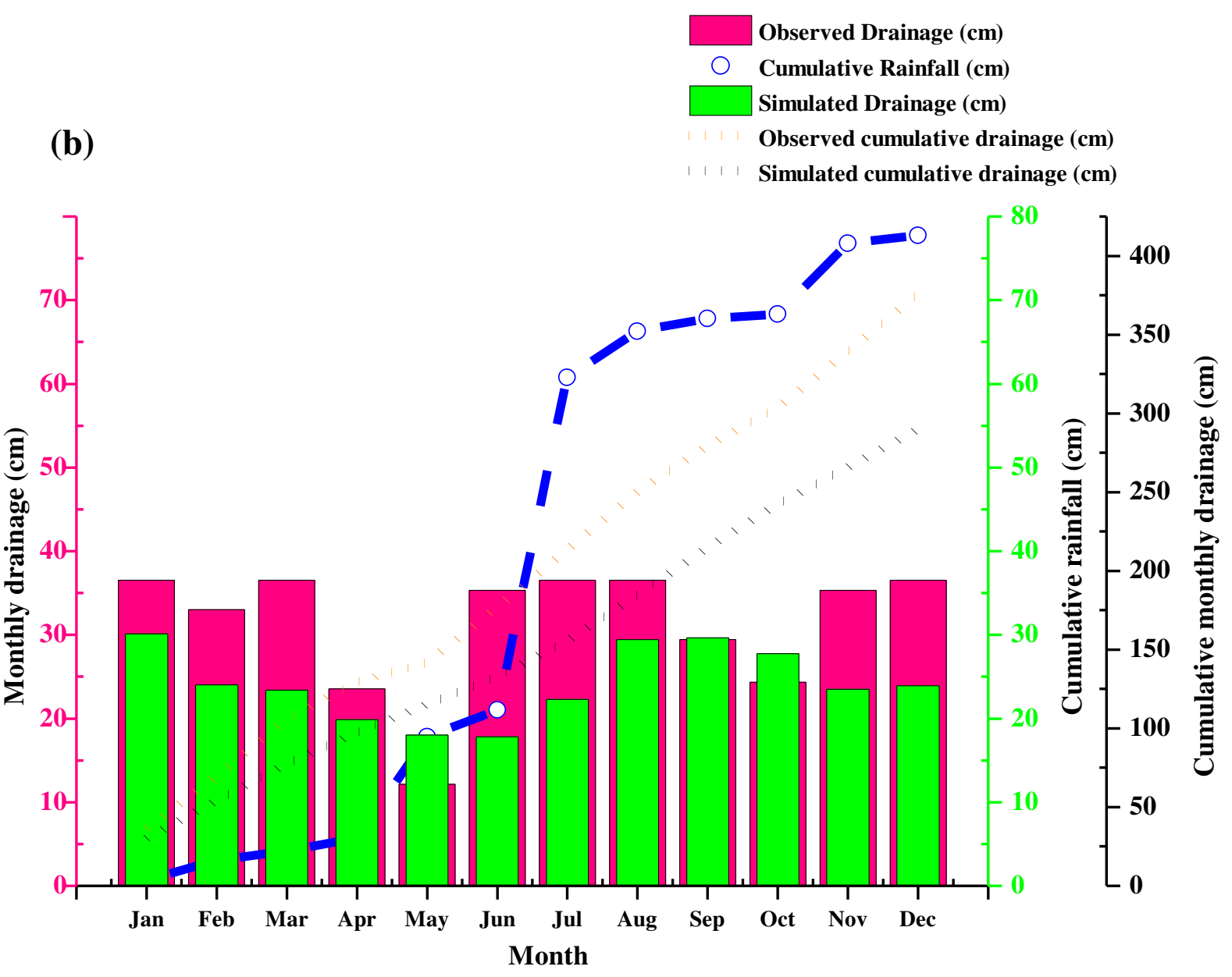

Fig.5. Observed and simulated monthly and cumulative drain outflows for rice- wheat cropping system during calibration period (a) 2018 (b) 2019

In the calibration period, the average of simulated daily drainage discharges during the rice wheat season $\left(0.88 \mathrm{~cm} \mathrm{day}^{-1}\right)$ was closer to that observed $\left(1.02 \mathrm{~cm} \mathrm{day}^{-1}\right)$. Flow events during the growing season are predicted well, but there are discrepancies in the magnitude of some events, especially during wet months, such as June and July, when drainage was under-estimated. Since, subsurface drainage and evapotranspiration are the two main pathways of water loss considered in this simulation study's water balance, any over- or under-estimation of subsurface drainage is balanced by adjustments in simulated ET. Actual ET is calculated using daily potential ET and soil moisture availability within the crop rooting depth by the DRAINMOD model. Daily potential ET was calculated using the Thornthwaite equation and crop 
coefficients by (Allen et al., 1998) as input to the model in this modeling research. Actual crop water use

251 varies on year-to-year basis depending on moisture availability, and crops can change their water use by

252 their rooting depth. In the summers of 2018 and 2019, simulated drain flow depths matched well with the

253 observed drain flow depths, but drainage was underestimated in June and July. This implies that better ET

254 estimation will help the model perform better. However, this is only possible if more accurate weather data

255 or calculated crop ET are available at the desired location.

\section{$256 \quad 3.1 .2$ Simulated nitrate loads}

In many studies, the movement of $\mathrm{NO}_{3}-\mathrm{N}$ has been linked to the movement of water in agricultural

258 soils (Armstrong and Burt, 1993). Figure 6 depicts the effects of daily and accumulated $\mathrm{NO}_{3}-\mathrm{N}$ losses in

259 subsurface drainage. Table 6 shows the statistical indices estimated for the predicted and observed daily

$260 \mathrm{NO}_{3}-\mathrm{N}$ losses. The calibration for the study area appears to be satisfactory, and the total expected $\mathrm{NO}_{3}-\mathrm{N}$

261 losses are in good agreement with the observed values, as shown in Fig. 6. The cumulative predicted $\mathrm{NO}_{3}-$

$262 \mathrm{~N}$ losses of $32.15 \mathrm{~kg} \mathrm{ha}^{-1}$ was recorded during the growing season in subsurface drainage over the

263 calibration period which was $2.9 \%$ less than the observed $\mathrm{NO}_{3}-\mathrm{N}$ losses of $33.07 \mathrm{~kg} \mathrm{ha}^{-1}$. King et al. (2015)

264 analyzed the effects of crop type and season on subsurface drainage discharge and nutrient loads.

265 "Bjorneberg et al. (1996) reported over a three-year period in Iowa that up to 85\% of annual tile flow and

$266 \mathrm{NO}_{3}-\mathrm{N}$ loads from a corn-soybean and continuous corn rotation on loam soils occurred during the non-

267 growing seasons. The averages of daily simulated and measured $\mathrm{NO}_{3}-\mathrm{N}$ losses were, 1.53 and $1.57 \mathrm{~kg}$ ha

$268{ }^{1}$, respectively during calibration (Table 8) under the rice wheat growing season. The $\mathrm{NO}_{3}-\mathrm{N}_{\text {losses in }}$ drain 269 outflows were strongly dependent on outflow rates in the study area. The calibrated and validated daily 270 drain flows were significantly different than their corresponding simulated values (Table 8) when confirmed 271 using t teat at 5\% level of significance. Following the under-estimated drainage outflows, DRAINMOD272 NII slightly under estimated the nitrogen losses in June, July, December and January months of both years 273 during the calibration period (Fig.6). Similar under estimations were reported by Salazar et al. (2009) and 274 Hassanpour et al. (2011). Higher $\mathrm{NO}_{3}-\mathrm{N}$ concentrations in drainage water in the years 2018-2019 growing 275 season could partly be due to more urea application. The grower applied $287 \mathrm{~kg} \mathrm{ha}^{-1}$ urea in rice and 337 
$276 \mathrm{~kg} \mathrm{ha}^{-1}$ in wheat during this season. During the experiment, Kladivko et al. (2004) reported a substantial

277 decrease in nitrate concentration in drainage water as a result of both the addition of a winter cover crop

278 and a reduction in fertilizer $\mathrm{N}$ applications. Jafari-Taloukolaee et al. (2018) reported on the effectiveness of

279 subsurface drainage systems in improving the soil structure of the study area by providing improved

280 conditions for soil aeration and increased saturated hydraulic conductivity. Such improvement could

281 eventually lead to the formation of flow paths from the soil surface to drains, which could be a major

282 contributor to rising $\mathrm{NO}_{3}-\mathrm{N}$ concentrations variation. However, increased nitrate losses, particularly after

283 fertilization or heavy rainfall, may have negative implications for receiving water bodies. Special

284 management techniques, on the other hand, should be used to control nitrate losses in light-textured

285 subsurface drained soils

Simulated Nitrogen Loss (Kg/ha)

- Observed cumulative Nitrogen Loss (Kg/ha)

- Simulated cumulative Nitrogen Loss (Kg/ha)

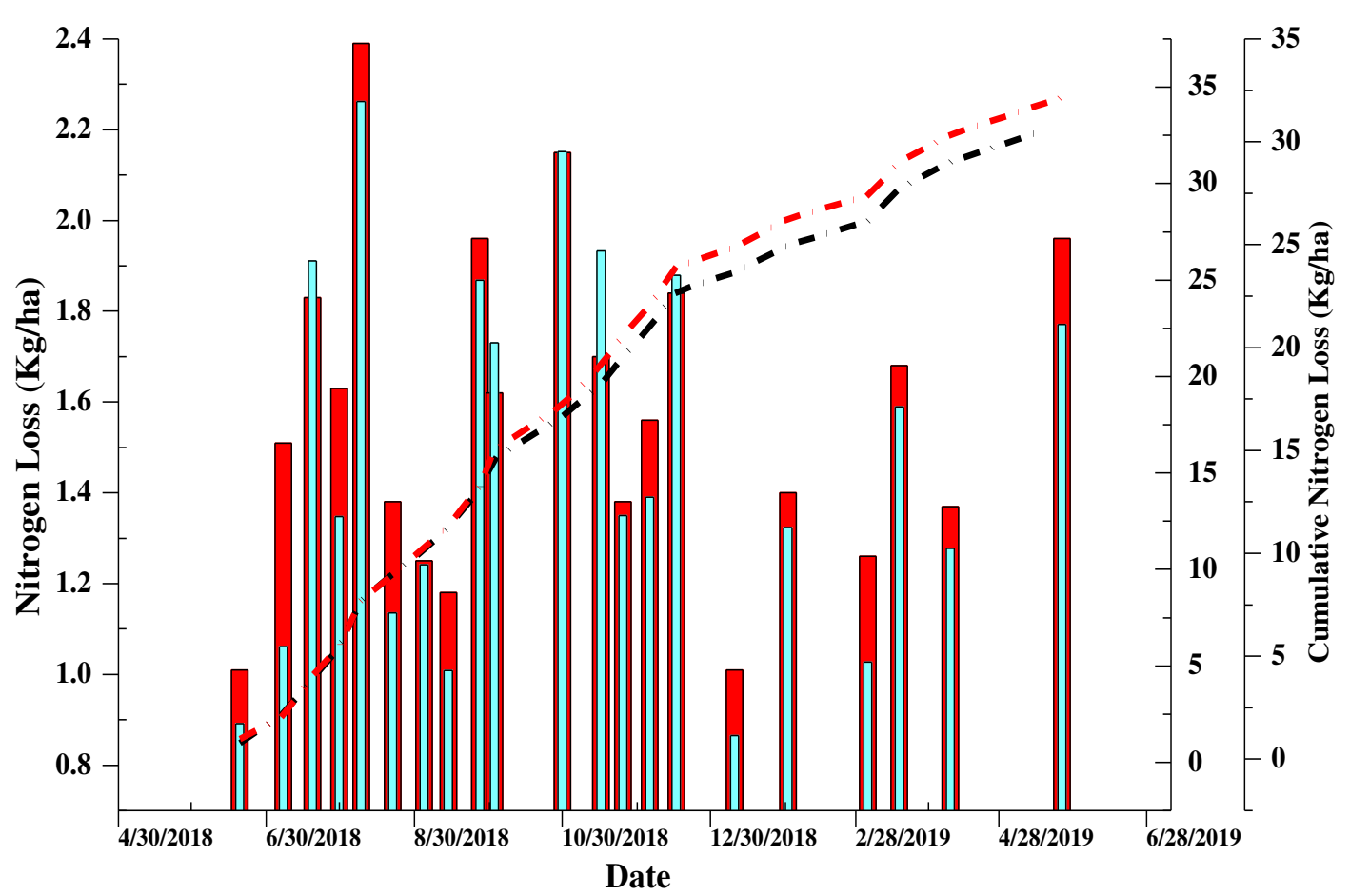

Fig.6. Observed, simulated and cumulative nitrogen losses in subsurface drains for rice- wheat 


\subsubsection{Simulated drainage outflows}

The experimental plot data was used to validate the calibrated model DRAINMOD-N II for the period (2019-2020). As shown in Figs.7 (a and b), the results visually indicate strong agreement between the field measurements and the simulated values for monthly drainage outflows. The comparisons were tested using t test, whereby the differences between observed and simulated drainage outflows were nonsignificant for the year 2018 while as significant difference was found in the years 2019 and 2020 , respectively. The DRAINMOD-NII model predicted values of monthly subsurface drainage outflows matched well with the observed data, during the validation period, except in the months of March, June and July of 2019 and 2020 respectively (Fig.7. a and b). This may be due to, differences in precipitation between the rain gauge site and experimental plots, which might probably, have affected predictions in March (having observed subsurface drain outflow of $36.51 \mathrm{~cm}$ and precipitation $1.06 \mathrm{~cm}$ ), June and July (having observed subsurface drain outflow of $35.36,36.51$ and precipitation of 3.2 and $39.74 \mathrm{~cm}$, respectively). In March, June of 2020 also, the observed subsurface drain outflows were (36.50 and $35.34 \mathrm{~cm}$, respectively) which was unrealistically very high (79\% and $88 \%)$ when compared to precipitation $(7.33 \mathrm{~cm}$ and $4.2 \mathrm{~cm}$ respectively). Overall, the model performance during the validation period was "good" with NSE $=0.47$; PBIAS=19.52; RMSE=9.66; $\mathrm{R}^{2}=0.53$ (Table 7). The predicted monthly subsurface drainage values were more variable compared to observed data, as indicated by larger than calibrated PBIAS values in case of simulated data (Table 7). The cumulative predicted subsurface drainage outflow of $296.57 \mathrm{~cm}$ was recorded over the entire validation periods, which was $20 \%$ lower than the observed subsurface drain outflow of $376.45 \mathrm{~cm}$. The average of simulated daily drainage discharges was $0.84 \mathrm{~cm}^{\text {day }}{ }^{-1}$ during the rice-wheat cropping season which was closer to that of the observed $1.08 \mathrm{~cm} \mathrm{day}^{-1}$, during the validation period. During the two growing seasons, there were more discrepancies between simulated and observed drain discharges in both the calibration and validation processes. The major reason for such discrepancy in the model can also be related to the differences in soil conditions and rainfall amount and pattern in different 
growing seasons. After a precipitation or irrigation event, the infiltrated water is used to replenish the moisture lost from the dry zone first, and the remaining portion joins the excess soil moisture, eventually causing a rise in water table. An under-estimation of drainage outflow may occur when a portion of

317 precipitation was used to replenish the dry zone, resulting in lower water table rise than expected. During 318 rainfall events, model predictions were usually lower than observed values, suggesting that simulated 319 effects were more unpredictable. Due to the existence of a hard pan layer below the plough pan of the study field (Darzi-Naftchali et al., 2013), part of the excess water travels horizontally in the plough layer to a drain trench, then vertically to a drain pipe. The vertical hydraulic conductivity or vertical resistance of the soil layer beneath the plough pan significantly influences flow to drains under these conditions, which was not taken into account in DRAINMOD simulations. After evaluating uncertainties related to DRAINMOD predictions for drainage outflows, Wang et al. (2006) concluded that vertical saturated hydraulic conductivity of the restrictive layer is the most sensitive parameter. The different paths of seepage were not included in the current analysis, with the exception of vertical seepage, which forms a major part of the water balance. It is said to have a significant impact on the DRAINMOD model predictions (Chang et al., 1983), which depend on exact quantification of all water balance components.

Table 7 Model performance during validation period (2019-2020) for rice wheat cropping system

\begin{tabular}{|l|l|l|l|l|}
\hline Parameter & RMSE & $\begin{array}{l}\text { PBIAS } \\
(\%)\end{array}$ & $\begin{array}{l}\text { Nash-Sutcliffe } \\
\text { coefficient (NSE) }\end{array}$ & $\mathbf{R}^{2}$ \\
\hline Drain flow depth & 9.66 & 19.52 & 0.47 & $0.53^{*}$ \\
\hline Nitrogen load & 0.12 & -5.19 & 0.82 & $0.85^{*}$ \\
\hline
\end{tabular}

$* \mathrm{R}^{2}$ is statistically significant, using partial $\mathrm{F}$ test for $\mathrm{p}=1$ and $\alpha=5 \%$ 


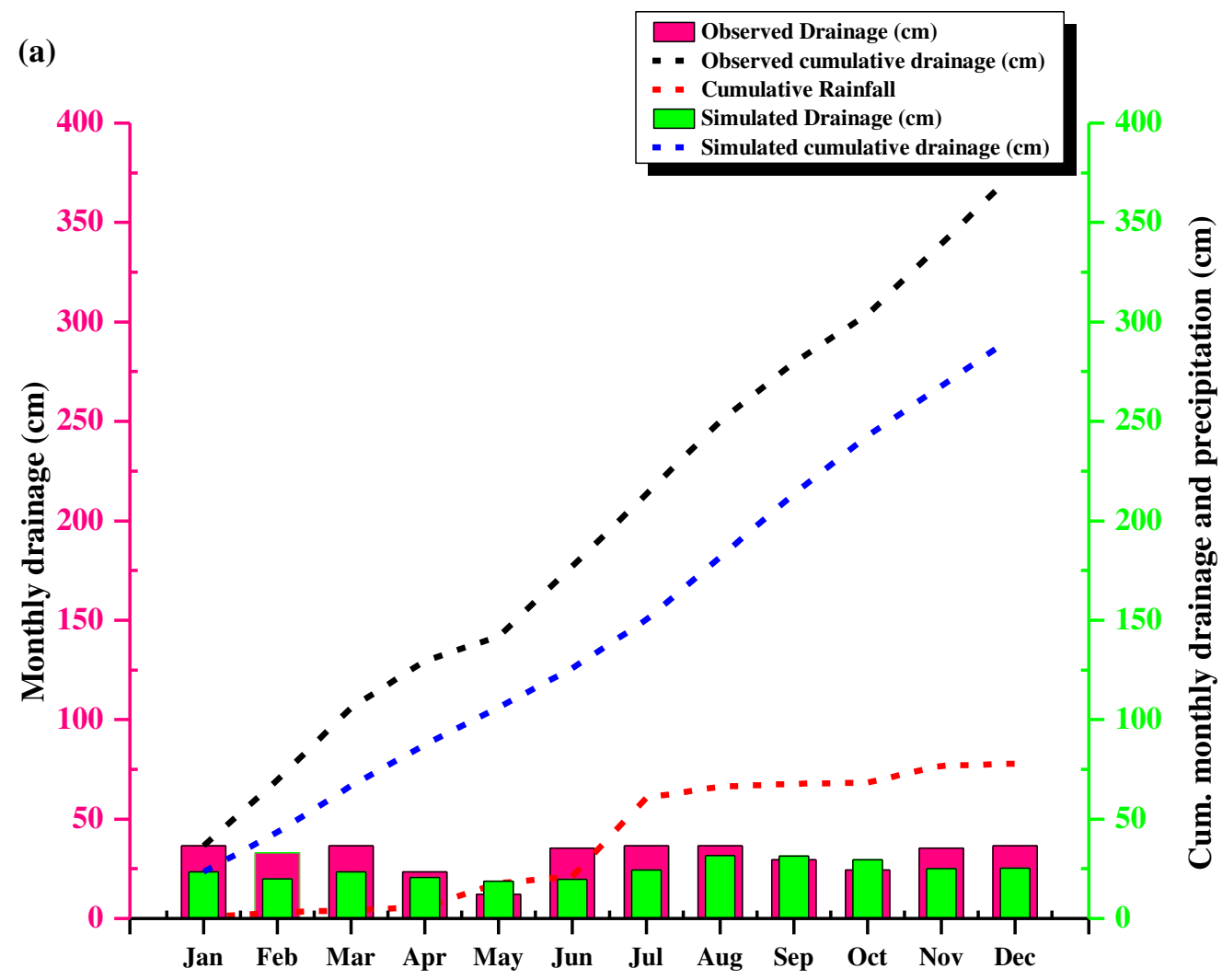

Month 


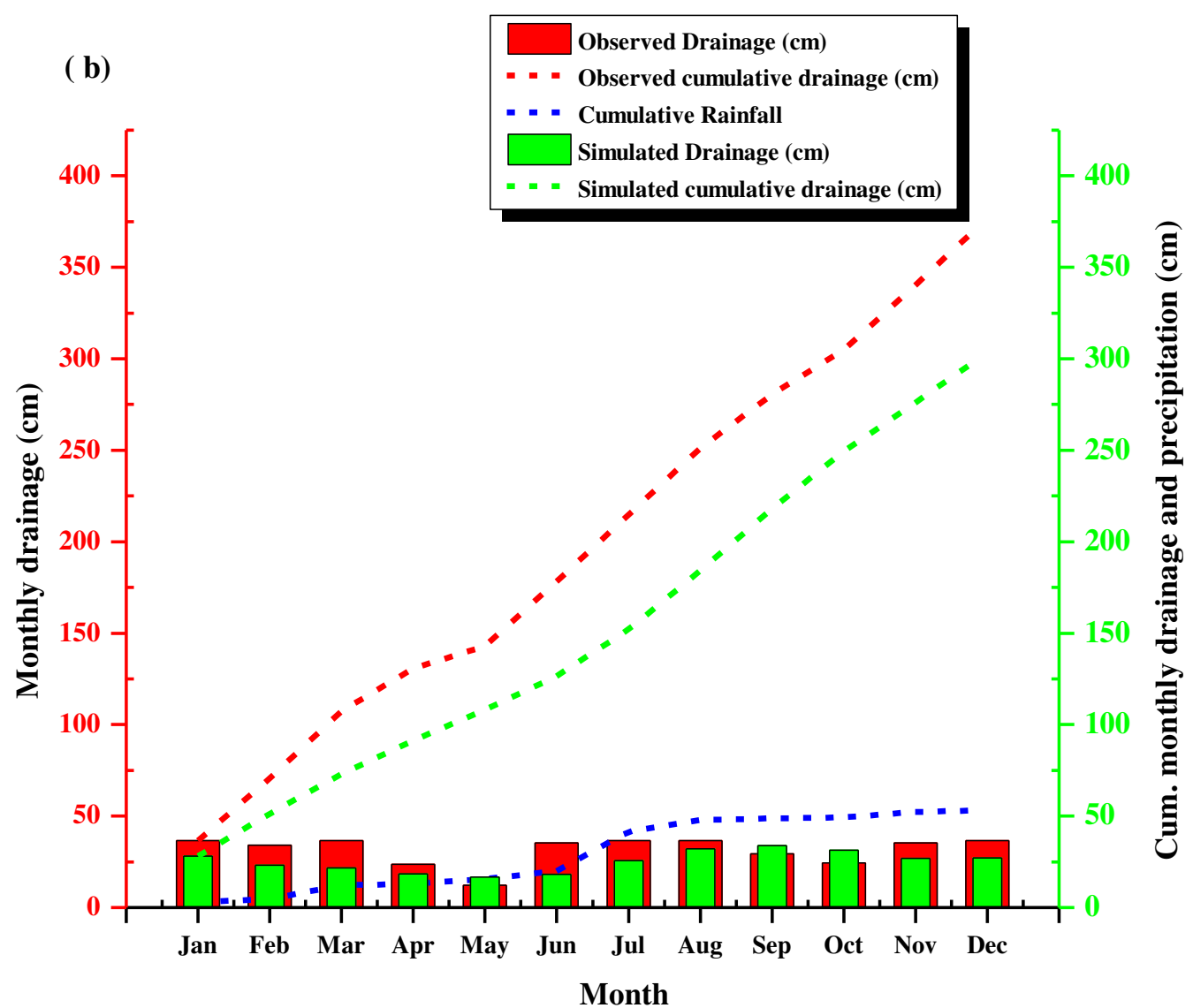

Month

Fig. 7. Observed and simulated monthly and cumulative drain outflows for rice- wheat system during validation period (a) 2019 (b) 2020

\subsubsection{Simulated nitrate loads}

The values of statistical parameters comparing simulated and observed $\mathrm{NO}_{3}-\mathrm{N}$ losses were lower

341 in validation period than in calibration (Table 7). The PBIAS value was $-5.19 \mathrm{~kg} \mathrm{~N}^{-1}$, the modelling

342 efficiency (NSE) was 0.82 and $\mathrm{R}^{2} 0.85$. The slightly lower agreement shown by statistical parameters for

343 validation when compared with calibration period was caused by a few events with larger discrepancies

344 between the simulated and observed $\mathrm{NO}_{3}-\mathrm{N}$ losses (Fig. 8). The majority of these discrepancies occurred 
in the months of July, November and January (Table 8), in the remaining months, predicted $\mathrm{NO}_{3}-\mathrm{N}_{\text {losses }}$

346 in subsurface drainage matched well with the observed losses. The predicted $\mathrm{NO}_{3}-\mathrm{N}$ losses in subsurface

347 drainage were much less variable compared to observed data (Fig. 8). The cumulative predicted $\mathrm{NO}_{3}-\mathrm{N}$

348 losses of $28.77 \mathrm{~kg} \mathrm{ha}^{-1}$ was recorded in subsurface drainage over the validation period which was $6.5 \%$

349 more than the observed $\mathrm{NO}_{3}-\mathrm{N}$ losses of $26.88 \mathrm{~kg} \mathrm{ha}^{-1}$. The model might have under predicted

350 denitrification during the validation period, leaving more mineral $\mathrm{N}$ susceptible to leaching in the drainage

351 outflow (Fig.8). It is possible that the overprediction of model for $\mathrm{N}$ mineralization rates, could partly

352 contribute to the errors in predicting $\mathrm{NO}_{3}-\mathrm{N}$ losses with drain outflow during these periods. Neither $\mathrm{N}$

353 mineralization nor denitrification was possible to measure, in the field to test the accuracy of model

354 prediction for these quantities. However, the value of these parameters was taken from the literature rather

355 than field and laboratory values that may cause some errors in predicting monthly $\mathrm{NO}_{3}-\mathrm{N}$ drainage losses using DRAINMOD-NII model.

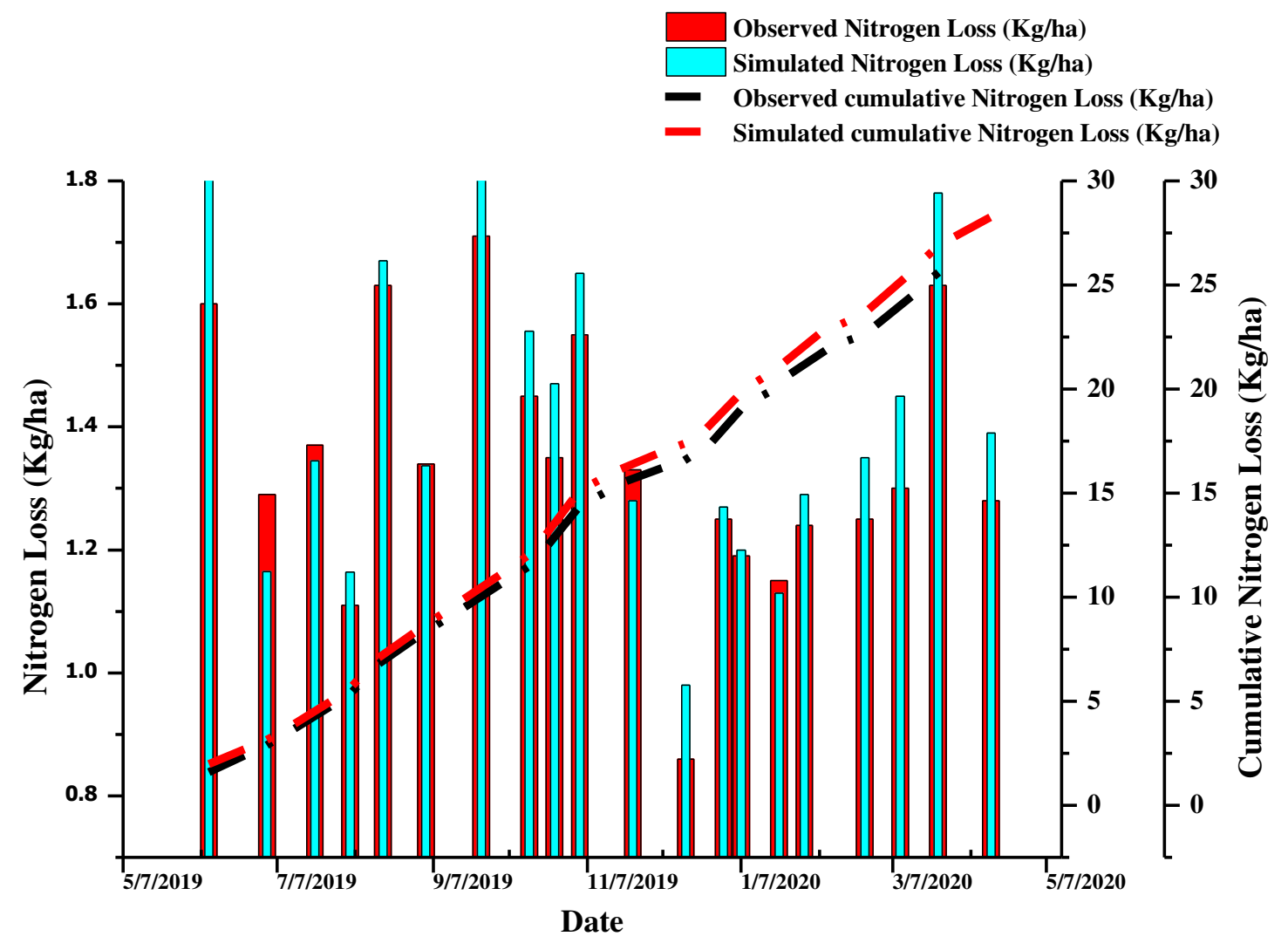


358 Fig. 8. Observed, simulated and cumulative nitrogen losses in subsurface drains for rice- wheat 359 cropping system during validation period

360

361

362

363 
Table 8 Observed and simulated daily drain discharge $\left(\mathrm{cm} \mathrm{day}^{-1}\right)$ and $\mathrm{NO}_{3}-\mathrm{N}$ loss $\left(\mathrm{kg} \mathrm{ha}^{-1}\right)$ during the study period

\begin{tabular}{|c|c|c|c|c|c|}
\hline Crop growing season & Day of Sampling & $\begin{array}{l}\text { Observed drain flow } \\
\left(\mathrm{cm} \mathrm{day}^{-1}\right)\end{array}$ & $\begin{array}{l}\text { Observed } \mathrm{NO}_{3}-\mathrm{N} \text { loss } \\
(\mathrm{kg} / \mathrm{ha})\end{array}$ & $\begin{array}{l}\text { Simulated } \\
\text { drain flow (cm } \\
\left.\text { day }^{-1}\right)\end{array}$ & $\begin{array}{l}\text { Simulated } \\
\mathrm{NO}_{3}-\mathrm{N} \quad \text { loss } \\
\text { (kg/ha) }\end{array}$ \\
\hline \multirow[t]{13}{*}{ 2018-19 } & 19-Jun-18 & 1.16 & 1.01 & $0.62 * *$ & $0.96^{*}$ \\
\hline & 07-Jul-18 & 1.17 & 1.51 & $0.70 * *$ & $1.14 *$ \\
\hline & 19-Jul-18 & 1.15 & 1.83 & $0.81 * *$ & $1.94 *$ \\
\hline & 30-Jul-18 & 1.14 & 1.63 & $0.87 * *$ & $1.41 *$ \\
\hline & 08-Aug-18 & 1.15 & 2.39 & $0.97 * *$ & $2.27 *$ \\
\hline & 21-Aug-18 & 1.18 & 1.38 & $0.98 * *$ & $1.21 *$ \\
\hline & 03-Sep-18 & 0.98 & 1.25 & $1.14 * *$ & $1.31 *$ \\
\hline & 13-Sep-18 & 0.95 & 1.18 & $1.14 * *$ & $1.09 *$ \\
\hline & 26-Sep-18 & 0.97 & 1.96 & $1.13^{* *}$ & $1.90 *$ \\
\hline & 02-Oct-18 & 0.78 & 1.62 & $1.10 * *$ & $1.77 *$ \\
\hline & $30-$ Oct-18 & 0.72 & 2.15 & $0.97 * *$ & $2.16^{*}$ \\
\hline & 15-Nov-18 & 1.17 & 1.70 & $0.91 * *$ & $1.96^{*}$ \\
\hline & 24-Nov-18 & 1.15 & 1.38 & $0.88^{* * *}$ & $1.41 *$ \\
\hline
\end{tabular}




\begin{tabular}{|c|c|c|c|c|c|}
\hline & 05-Dec-18 & 1.19 & 1.56 & $0.84 * *$ & $1.45^{*}$ \\
\hline & 16-Dec-18 & 1.11 & 1.84 & $0.89 * *$ & $1.91^{*}$ \\
\hline & 09-Jan-19 & 1.12 & 1.01 & $1.00 * *$ & $0.95^{*}$ \\
\hline & 31-Jan-19 & 1.10 & 1.40 & $0.91 * *$ & $1.38^{*}$ \\
\hline & 05-Mar-19 & 1.13 & 1.26 & $0.79 * *$ & $1.10 *$ \\
\hline & 18-Mar-19 & 1.11 & 1.68 & $0.74 * *$ & $1.63^{*}$ \\
\hline & 08-Apr-19 & 0.78 & 1.37 & $0.68 * *$ & $1.34 *$ \\
\hline & 24-Мay-19 & 0.39 & 1.96 & $0.56^{* * *}$ & $1.80^{*}$ \\
\hline & Average & 1.02 & 1.57 & 0.88 & 1.52 \\
\hline & SD & 0.20 & 0.36 & 0.16 & 0.39 \\
\hline \multicolumn{6}{|l|}{ 2019-20 } \\
\hline & 10-Jun-19 & 1.17 & 1.60 & $0.63 * *$ & $1.98 *$ \\
\hline & 03-Jul-19 & 1.16 & 1.29 & $0.72 * *$ & $1.16^{*}$ \\
\hline & 22-Jul-19 & 1.18 & 1.37 & $0.84 * *$ & $1.34 *$ \\
\hline & 05-Aug-19 & 1.17 & 1.11 & $0.89 * *$ & $1.16^{*}$ \\
\hline & 18-Aug-19 & 1.10 & 1.63 & $1.09 * *$ & $1.67 *$ \\
\hline & 04-Sep-19 & 0.98 & 1.34 & $1.03 * *$ & $1.33 *$ \\
\hline & 26-Sep-19 & 0.96 & 1.71 & $1.03 * *$ & $1.82 *$ \\
\hline
\end{tabular}




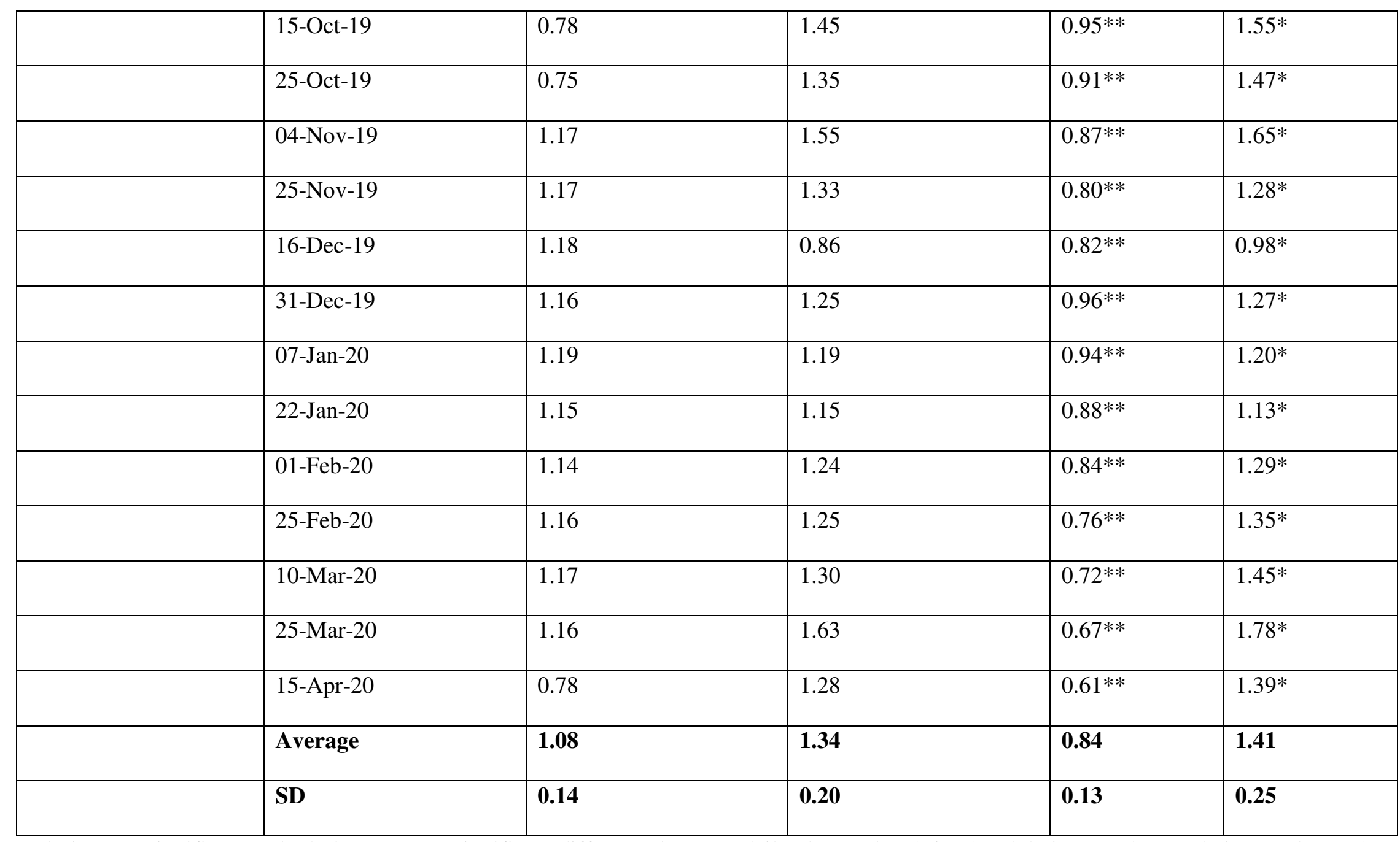

**designates Significant and *designates Non-significant difference between daily observed and simulated drainage values and nitrogen loss values at $5 \%$ level of significance using $t$ test 


\section{Conclusions}

DRAINMOD-NII was successfully calibrated and validated over a two-year cultivation period in Thehri, Muktsar, Punjab, using data sets from conventional drained plots. The statistical comparison of simulated and observed drain flows and nitrogen losses revealed a stronger agreement with some discrepancies between the two data sets. For the DRAINMOD-N II, statistical goodness-of-fit measurements such as root mean square error (RMSE), percentage of bias (PBIAS), modeling efficiency (NSE), and coefficient of determination $\left(\mathrm{R}^{2}\right)$ confirm that the model results and field observations are in strong agreement. The findings show that DRAINMOD-N II has the ability to simulate drainage rates and nitrogen losses from agricultural lands in Indian conditions for newly reclaimed lands. However, since this model was only tested for a shorter time period and with a single cropping method, inconsistencies that caused conflict with a specific set of values must be resolved for wider application of this model.

\section{Acknowledgment}

The authors would like to express their thanks to every person associated with this study, especially Drainage Department, Govt. of Punjab, India, for providing the subsurface drainage facility and the farmers involved at the study location. The research presented in this paper was supported financially in part by the HRDG CSIR, New Delhi under the Senior Research Fellowship with award letter 09/272(0137) 2018EMR-1 is duly acknowledged.

\section{Conflict of Interest}

The authors declare no competing interests

\section{Funding statement}

The research presented in this paper was supported financially in part by the HRDG CSIR, New Delhi under the Senior Research Fellowship(direct) programme with award letter 09/272(0137) 2018-EMR-1

\section{Author's Contribution}

Methodology, Software, writing-original draft, visualization: Mehraj U Din Dar Conceptualization, investigation: Mehraj U Din Dar 
Supervision: J.P. Singh

Resources: J.P. Singh

Review and editing, result interpretation: Mehraj U Din Dar, J.P. Singh

Review and editing: Mehraj U Din Dar, J.P. Singh

Availability of data and material

Data will be furnished upon request

\section{Code availability}

The codes used if any will be shared upon request

\section{Ethics approval}

Not applicable

\section{Consent to participate}

Consent taken from the authors

\section{Consent for publication}

Consent given by all authors

\section{References}

Ale, S., Bowling, L. C., Youssef, M. A., Brouder, S. M., 2012.Evaluation of simulated strategies for reducing nitrate-nitrogen losses through subsurface drainage systems. J. Environ. Qual. 41(1), 217-228.

Allen, R. G., Pereira, L. S., Raes, D., 1998. Smith Crop evapotranspiration: guidelines for computing crop water requirements FAO Irrigation and Drainage Paper No. 56, FAO, Rome, Italy 300 pp.

Armstrong, A. C., Burt, T. P., 1993. Nitrate losses from agricultural land. In: Burt, T. P., Heathwaite, A. L., and Trudgill, S. T., (eds) Nitrate: Processes, Patterns and Management. pp 239-267. Wiley, Chichester Bjorneberg, D. L., Kanwar, R. S., Melvin, S. W., 1996. Seasonal changes in flow and nitrate-N loss from subsurface drains. Trans. ASAE. 39(3), 961-967.

Carpenter, S.R., Caraco, N.F., Correll, D.L., Howarth, R.W., Sharpley, A.N., Smith, V.H., 1998. Nonpoint pollution of surface waters with phosphorus and nitrogen. Ecol. Appl. 8 (3), 559-568. 
Chang, A. C., Skaggs, R. W., Hermsmeier, L. F., Johnson, W. R., 1983. Evaluation of a water management model for irrigated agriculture. Trans. ASAE. 27, 412-418.

Darzi-Naftchali, A., Mirlatifi, S. M., Shahnazari, A., Ejlali, F., Mahdian, M. H., 2013. Effect of subsurface drainage on water balance and water table in poorly drained paddy fields. Agric. Water Manage.130, 6168.

David, M.B., Gentry, L.E., Kovacic, D.A., Smith, K.M., 1997. Nitrogen balance in and export from an agricultural watershed. J. Environ. Qual. 26 (4), 1038-1048.

Evans, R.O., Skaggs, R.W., Sneed, R.E., 1991. Stress day index models to predict corn and soybean relative yield under high water table conditions. Trans. ASAE. 34,1997-2005.

Fausey, N. R., Brown, L. C., Belcher, H. W., Kanwar, R. S., 1995. Drainage and water quality in Great Lakes and Cornbelt states. J. Irri. Drain. Engg. 121 (4), 283 -288.

Gentry, L. E., David, M. B., Smith, K. M., Kovacic, D. A.,1998. Nitrogen cycling and tile drainage nitrate loss in a corn/soybean watershed. Agric. Ecosys. Environ. 68(1-2), 85-97.

Government of Punjab., 2008. The Statistical Abstract of Punjab, Various Issues, Economic Adviser to Government of Punjab, Economic and Statistical Division, Punjab, Chandigarh.

Gupta, H.V., Sorooshian, S., Yapo, P.O.,1999. Status of automatic calibration for hydrologic models: Comparison with multilevel expert calibration. J. Hydrol. Eng. 4, 135-143.

Gupta, S. K., Kamra, S. K., 2006. Water logging, Environment and Agriculture. Pp.98. Malhotra Publishing House, New Delhi.

Gupta, S.K., 2002. A century of subsurface drainage research in India. Irrig. Drain. Sys. 16, 69-84. 
Hassanpour, B., Parsinejad, M., Yazdani, M. R., Dalivand, F. S., Kossari, H., 2011. Evaluation of modified DRAINMOD in predicting groundwater table fluctuations and yield of canola in paddy fields under snowy conditions (case study: Rasht Iran). Irri. Drain. 60(5), 660-667.

Hay, R.K., 1995. Harvest index: a review of its use in plant breeding and crop physiology. Ann. Appl. Biol. $126,197-216$.

Hoad, S.P., Russell, G., Lucas, M.E., Bingham, I. J., 2001. The management of wheat, barley, and oat root systems. Adv. Agron. 74, 193-246

Jacobs, T.C., Gilliam, J.W., 1985. Riparian losses of nitrate from agricultural drainage waters. J. Environ. Qual. 14 (4), 472-478

Jafari Talukolaee, M., Darzi-Naftchali, A., Zare- Parvariji, L., Ahmadi, M. Z., 2018. Investigating longterm effects of subsurface drainage on soil structure in paddy fields. Soil. Tillage Res. 177, 155-160.

King, K. W., Williams, M. R., Fausey, N. R., 2015. Contributions of systematic tile drainage to watershedscale phosphorus transport. J. Environ. Qual. 44, 486-94. https://doi.org/10.2134/jeq2014.04.0149.

Kladivko, E. J., Frankenberger, J. R., Jaynes, D. B., Meek, D. W., Jenkinson, B. J., Fausey, N. R., 2004 Nitrate leaching to subsurface drains as affected by drain spacing and changes in crop production system. J. Environ. Qual. 33, 1803 - 1813.

Kladivko, E. J., Frankenberger, J. R., Jenkins, B. J., Fausey, N. R., 2004. Nitrate losses to subsurface drains as affected by winter cover crop, fertilizer $\mathrm{N}$ rates, and drain spacing. ASAE Paper No. 701P0304. Michigan, USA

Ladha, J.K., Fischer, K.S., Hossain, M., Hobbs, P.R., Hardy, B. (Eds.), 2000. Improving the productivity and sustainability of rice-wheat systems of the Indo-Gangetic plains: a synthesis of NARS-IRRI partnership research. IRRI Discussion Paper Series No. 40, IRRI, Los Banos, Philippines. 
Moriasi, D. N., Arnold, J. G., Van Liew, M. W., Bingner, R. L., Harmel, R. D., Veith, T. L., 2007. Model evaluation guidelines for systematic quantification of accuracy in watershed simulations. Trans. ASABE. 50(3), 885-900.

Nash, J.E., Sutcliffe, J.V., 1970. River flow forecasting through conceptual models: Part 1. A discussion of principles. J. Hydrol. 10, 282-290.

Randall, G. W., Mulla, D. J., 2001. Nitrate nitrogen is surface waters as influenced by climatic conditions and agricultural practices. J. Environ. Qual. 30, 337-344.

Salazar, O., Wesström, I., Youssef, M. A., Skaggs, R. W., Joel, A., 2009. Evaluation of the DRAINMODN II model for predicting nitrogen losses in a loamy sand under cultivation in south-east Sweden. Agric. Water Manage. 96(2), 267-281.

Santhi, C., Arnold, J.G., Williams, J.R., Dugas, W.A., Srinivasan, R., Hauck, L.M., 2001. Validation of the SWAT Model on a Large River Basin with Point and Nonpoint Sources. J. Am. Water Resour. Assoc. 37, $1169-1188$.

Shedekar, V. S., King, K. W., Fausey, N. R., Islam, K. R., Soboyejo, A. B., Kalcic, M. M., Brown, L. C., 2021. Exploring the effectiveness of drainage water management on water budgets and nitrate loss using three evaluation approaches. Agric. Water Manage. 243, 106501.

Singh, A., 2012. Development and application of a water table model for the assessment of waterlogging in irrigated semi-arid regions. Water Resour. Manage. 26 (15), 4435-4448.

Singh, J., Knapp, H. V., Demissie, M., 2004. Hydrologic modeling of the Iroquois River watershed using HSPF and SWAT. ISWS CR 2004-08. Champaign, Ill.: Illinois State Water Survey. Available at: www.sws.uiuc.edu/pubdoc/CR/ISWSCR2004-08.pdf. Accessed 8 September 2005 
Skaggs, R. W., Fausey, N. R., Evans, R. O., 2012. Drainage water management. J. Soil Water Conserv. 67(6), 167A-172A.

Skaggs, R.W., Youssef, M.A., Chescheir, G.M., 2012. DRAINMOD: model use, calibration and validation, Trans. ASABE. Am. Soc. Agric. Biol. Eng. 55 (4), 1509-1522, ISSN 2151-0032.

Stoate, C., Boatman, N.D., Borralho, R.J., Rio Carvalho, C., De Snoo, G.R., Eden, P., 2001. Ecological impacts of arable intensification in Europe. J. Environ. Manage. 63 (4), 337-365.

Thornthwaite, C. W., 1948. An approach toward a rational classification of climate. Geograph. Rev. 38(1), $55-94$.

Tian, S., Youssef, M. A., Skaggs, R. W., Amatya, D. M., Chescheir, G. M., 2012. DRAINMOD-FOREST: Integrated modeling of hydrology, soil carbon and nitrogen dynamics, and plant growth for drained forests. J. Environ. Qual. 41(3), 764-82.

Uppal, H.L., Mangat, N.S., 1981. "Water logging in Muktsar Town and Adjacent Area- Its Causes and Remedies”. J. Inst. Engineer. (India).193-199.

Van Liew, M.W., Arnold, J.G., Garbrecht, J.D., 2003. Hydrologic simulation on agricultural watersheds: Choosing between two models. Trans. ASAE. 46, 1539-1551

Wang, X., Frankenberger, J. R., Kladivko, E. J., 2006.Uncertainties in DRAINMOD predictions of subsurface drain flow for an Indiana silt loam using the GLUE methodology. Hydrol. Process. Intnl. J. 20(14), 3069-3084.

Williams, M, R., King, K. W., Fausey, N. R., 2015. Drainage water management effects on tile discharge and water quality. Agric. Water Manage.148, 43-51. 
Youssef, M.A., 2003. Modeling Nitrogen Transport and Transformations in High Water Table Soils, Ph.D. diss, North Carolina State Univ., Raleigh, NC.

Youssef, M.A., Skaggs, R.W., Chescheir, G.M., Gilliam, J.W., 2005. The nitrogen simulation model, DRAINMOD-N II. Trans. ASAE 48 (2), 611-626

Youssef, M.Y., Skaggs, R.W., Chescheir, G.M., Gilliam, J.W., 2006. Field evaluation of a model for predicting nitrogen losses from drained lands, J. Environ. Qual. JEQ 35, 2026-2042 